\title{
The History of the Variation of the Infinitive Complement in Portuguese
}

\author{
Maria Auxiliadora da Fonseca Leal \\ Universidade Federal de Minas Gerais, Belo Horizonte, Brazil
}

\begin{abstract}
This paper has a synchronic/diachronic nature and aims at describing and characterizing variation of the complement $[\mathrm{de}+$ infinitive $][\varnothing+$ infinitive $]$ in five periods of Portuguese language, i.e., archaic Portuguese, classical Portuguese, 17th century Portuguese, 18th century Portuguese, and modern contemporary Portuguese. By means of data analysis from these five periods, it was possible to identify internal factors of the adjacency/non-adjacency, class of verbs, verbal tense, verbal mode, and grammatical person that bear the relationship of infinitive complementation in Portuguese. To accomplish the task, first we started investigating from the present period to the past period, returning afterwards to the present period like Labov (1972b) and making use of the software WordSmith Tools to analyse the data quantitatively. The description of the variable infinitive behaviour and their conditioning factors in each of the analysed synchrony was made. We verified that the phenomenon occurs in all phases of Portuguese language. This phenomenon is more recurrent in archaic phase, which is justified by the high rate of rupturing elements that are presented there. Diachronically, we verified that [de + infinitive $] \sim \varnothing+$ infinitive $]$ is stable, and throughout Portuguese history it is conditioned by a specific structural context, adjacency/non-adjacency, as well as by a certain class of verbs, here labeled as modal transitive verbs. We also observed that the number of regent verbs as well as prepositional infinitive structures decrease throughout time, but they do not disappear.
\end{abstract}

Keywords: [de + infinitive $] \sim[$ + infinitive $]$, diachrony, variation, internal factors, modal transitive verbs

The analysis of verbs that we conducted in this search is based in the corpora of five periods of the Portuguese language. The proposed analysis object is the constructions [de + infinitive] and $[\varnothing+$ infinitive] as a complement of verbal syntagma illustrated at:

(1a) "Ela evita de comer à noite" / (1a) "She avoids to eat at night".

(1b) "Nós evitamos falar sobre política" / (1b) "We avoid talking about politics".

The structures listed at (1) occur in all the phases of the Portuguese language, being more or less frequent according to the period observed. They are variables that can point out either a linguistics change phenomenon or a retention phenomenon.

The highlighted data illustrate a variation phenomenon of the contemporary Portuguese. The word variation, according to Tarallo (1986, p. 8), refers to the "theory of variation" that takes on the heterogeneity and the linguistic "caos" as study object. Now, variants are "set of linguistic forms that make a variable; they

Maria Auxiliadora da Fonseca Leal, associate professor, doctor, Faculdade de Letras, Universidade Federal de Minas Gerais (UFMG). 
can be standard, non standard, conservative, innovative, stigmatic and prestigious" (Tarallo, 1986, p. 12); in other words, the many ways of saying the same thing, in a same context, with the same value of truth.

We observed the factors that condition this variation, aiming to prove or not its status in the language, also for the fact that some variables represent stages in the movement from one linguistic state to another.

As acknowledged by Weinreich, Labov, and Herzog (1968, p. 188), in their third postulate for the theory of linguistic change, they affirm: "not all variability and heterogeneity in the structure of the language involves change, but every change involves variability and heterogeneity".

The "principles of standardization" were adopted by Labov (1995) and still kept in the variacionism says: "the forces that act to produce the old document are the same that act in the current language" (p. 21), therefore allowing the present-past movement.

We started our analysis from the facts/data of the present to glimpse the past and interpret historical data from the past to understand/interpret the present. We postulate, according to the "princípio uniformitário", in which the comparison between present and past (following, also, the neo-grammatical perspective) contemplates the fact that all kinds of linguistic changes would exist and occur in every phase of the history of languages.

The language periods examined were: the contemporary modern Portuguese (CMP) 19th-century Portuguese (NP), 18th-century Portuguese (EP), classic Portuguese (CP) of the second half of the XVI and XVII centuries and, at last, archaic Portuguese (AP), that is, the texts written in Portuguese, until the first half of the XVI century.

The conditioner factors, that is, the total set of possible phenomena that determinate the occurrence of variants in the systematization or not of the change, vary and alter constantly. According to Milroy (1992), "the data/information of variability are built from the principle that the language is variable all the time" (p. 123).

Synchronically, we investigated the infinitive complements connected to verbs that occurred at the corpora, with the goal to characterize them as prepositioned objective complements or not, according to the factors that condition this occurrence.

Diachronically, we compared the variation of the complementation and the kinds of verbs present, at the many periods studied, as possible indicators of "processes of change", "stable variation", or "maintenance phenomena".

The theoretical support follows the model of the Variation Theory, with typically Labovian base, which indicates the correlation of variables to linguistic variation phenomena, in what concerns: (1) the "fitting", that is, how a determinated change fits in the structural and social level and (2) the "transition" that allows to identify the intermediate phases in which the variants coexist and compete, gradually decreasing the occurrence of one and increasing the occurrence of the other.

For the quantitative analysis, we used the theoretical-methodological proposal of the Linguistics of Corpus, through the use of computer tools named "Concord" and "Tags" from the software "WordSmith Tools".

\section{The Corpora}

\section{Contemporary Modern Portuguese (CMP)}

(2a) "Dever-se-á evitar de levar comidas e/ou bebidas para as salas de correção".

(2a) "It shall be avoided to bring food and/or beverages to the correction rooms".

(2b) "O povo evita escolher candidatos sem formação como governantes" (Vestibular UFMG, 2002). 
(2b) "The people avoid choosing candidates without educational background as rulers" (Vestibular UFMG, 2002).

The construction (2a) registers the verb avoid connected to the complement by [de + infinitive], differently from the construction (2b) that points out the verb connected to the complement by [ $\varnothing+$ infinitive].

According to Houaiss, avoid can be direct transitive and bitransitive, displaying the renderings "escapar-se de (escape from), esquivar-se de (dodge from), não permitir (not to allow), poupar (spare)", etc. This verb also displays variation of the infinitive complement, with and without the preposition $d e$, in a way that the presence/absence interferes its meaning.

\section{9th-Century Portuguese (NP)}

(3a) “...a soberba cavaleira, de uma formosura invejável na Circássia, devia de ser a esposa raptada de algum grão-vizir; ...” (Amor de Salvação, Camilo Castelo Branco, p. 20).

(3a) "...the proud knight, of an enviable beauty at Cherkessia, should have been the stolen wife of some grand vizier; ...” (Amor de Salvação, Camilo Castelo Branco, p. 20).

(3b) “...e demonstre que o romance filosófico deve ser assim alinhavado ...” (Amor de Salvação, Camilo Castelo Branco, p. 24).

(3b) "...and show that the philosophical romance should be thus basted..." (Amor de Salvação, Camilo Castelo Branco, p. 24).

In the corpus of the 19th-century Portuguese also occurs the variation of the complement [de + infinitive $][\varnothing+$ infinitive $]$. In the works of this period's writers, such variation is recurrent, mostly to the verbs as should and need, in a way that the presence/absence of the preposition, in these contexts, does not chance the meaning of the verbs.

\section{8th-Century Portuguese (EP)}

(4a) "...e chorosos olhos em Natália e depois levantando-os ao Céu, prometeu de propor estes desejos..." (Novelistas e Contistas Portugueses, Manuel Bernardes, p. 270).

(4a) “...and teary eyes in Natália and then rising them to the Heavens, promised to propose these desires..." (Novelistas e Contistas Portugueses, Manuel Bernardes, p. 270).

(4b) “...dar satisfação à parte ofendida e alívio à sua consciência gravada, prometeu pagar o que se lhe demandava. O raro amor...” (Novelistas e Contistas Portugueses, Manuel Bernardes, p. 274).

(4b) "...to give satisfaction to the offended part and relief to his engraved consciousness, he promised to pay what was demanded of him. The rare love..." (Novelistas e Contistas Portugueses, Manuel Bernardes, p. 274).

\section{Classic Portuguese (CP)}

(5a) “...afeiçoada ao gesto belo e tenro, deseja de comprar-vos para genro” (Lusíadas, Camões).

(5a) "...fond to the beautiful and tender gesture, wishes to buy you as son in law" (Lusiadas, Camões).

(5b) "E mais lhe diz também que ver deseja" (Lusíadas, Camões).

(5b) "And more tells you also says that to see desires" (Lusíadas, Camões).

\section{Archaic Portuguese (AP)}

(6a) “...suptamente começaron de ouvir trovões...” (Narrativas dos Livros de Linhagens, José Mattoso, p. $80)$. 
(6a) “...suddenly started to hear thunder...” (Narrativas dos Livros de Linhagens, José Mattoso, p. 80).

(6b) "...E começou rei Ramiro entom seu corno tanger, e começou chamar sua gente pelo corno que the acorressem...” (Narrativas dos Livros de Linhagens, José Mattoso, p. 58).

(6b) "...And so started king Ramiro to peal his horns, and started calling his people by the horns to succor him..." (Narrativas dos Livros de Linhagens, José Mattoso, p. 58).

The variable linguistic phenomena under analysis are registered in all of the phases of the Portuguese language. It is needed to highlight the fact, already proven, that the language is variable in all its periods.

\section{Data Analysis}

Table 1

Percentage of the Overall Occurrence of the Structures [de + infinitive] and [Ø + infinitive] in the Five Periods Analyzed

\begin{tabular}{llllll}
\hline Period & {$[\mathrm{de}+$ inf. $]$} & $\%$ & {$[\varnothing+$ inf. } & $\%$ & Total \\
\hline AP & 1705 & $49.6 \%$ & 1730 & $50.4 \%$ & 3435 \\
CP & 197 & $35.9 \%$ & 352 & $64.1 \%$ & 549 \\
EP & 73 & $13 \%$ & 491 & $87 \%$ & 564 \\
NP & 197 & $16.7 \%$ & 979 & $83.3 \%$ & 1176 \\
CMP & 267 & $16.5 \%$ & 1351 & $83.5 \%$ & 1618 \\
Total & 2,439 & $33.3 \%$ & 4,903 & $66.7 \%$ & 7,342 \\
\hline
\end{tabular}

The results expressed in the Table 1 indicate the percentage of the overall occurrences of the constructions $[\mathrm{de}+$ infinitive $]$ and $[\varnothing+$ infinitive $]$ present in the five phases of the Portuguese language.

Diachronically, comparing the archaic period with the following periods, we observe that the frequency of occurrence of the complement [de + infinitive] decreases with time: from $49.6 \%$ in the archaic Portuguese to $16.5 \%$ in the contemporary modern Portuguese, and the occurrence of the complement [Ø + infinitive] increases from $50.4 \%$ in the AP to $83.5 \%$ in the CMP.

We present on Table 2 the overall occurrence of the variation [de + infinitive $] \sim[\varnothing+$ infinitive $]$ in the five periods of the language.

Table 2

Total Occurrences of the Variation [de + infinitive] [Ø + infinitive] in the Five Phases of the Language

\begin{tabular}{llllll}
\hline Period & {$[\mathrm{de}+$ inf.] } & $\%$ & {$[\varnothing+$ inf.] } & $\%$ & Total \\
\hline AP & 1580 & $48.7 \%$ & 1667 & $51.3 \%$ & 3247 \\
CP & 78 & $32.8 \%$ & 160 & $67.2 \%$ & 238 \\
EP & 37 & $10 \%$ & 335 & $90 \%$ & 372 \\
NP & 46 & $11.8 \%$ & 344 & $88.2 \%$ & 390 \\
CMP & 66 & $7.5 \%$ & 810 & $92.5 \%$ & 876 \\
Total & 1,807 & $35.5 \%$ & 3,316 & $64.5 \%$ & 5,123 \\
\hline
\end{tabular}

In what concerns the outlook of the variation present in the five researched periods, the Table 2 allows us to find, in quantitative terms, the decrease of the prepositioned variation in the CMP in relation to the AP. Considering the total of constructions in variation, the complement [de + infinitive] in the AP represents 48.7\% and in the CMP it corresponds to $7.5 \%$. Differently, the complement [Ø + infinitive] increases from $51.3 \%$ to $92.5 \%$. 
The following Figure 1 reveals the variation $[\mathrm{de}+$ infinitive $][\varnothing+$ infinitive $]$ in the five researched periods.

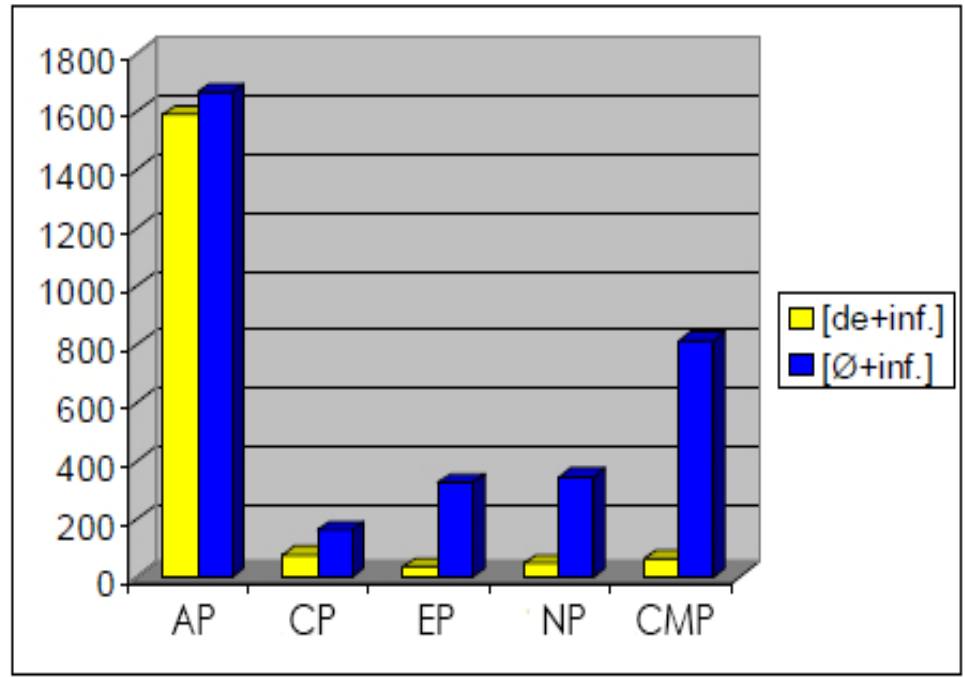

Figure 1. Variation $[\mathrm{de}+$ infinitive $] \sim[\varnothing+$ infinitive $]$ in the five researched periods.

Observe now, in the Figure 2, the percentage of the verbs in variation in the five analyzed periods.

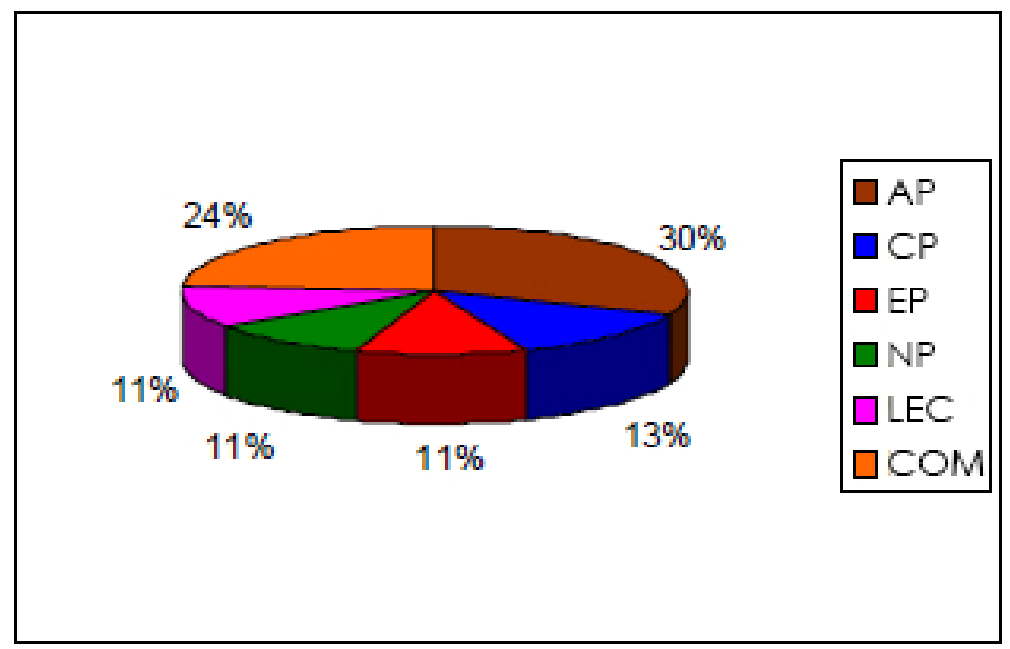

Figure 2. Percentage of the number of verbs that allow variation $[\mathrm{de}+$ infinitive $] \sim[\varnothing+$ infinitive $]$ in all the analyzed periods.

The Figure 2 indicates that the archaic period represents the biggest percentage of verbs in alternation, that is, (30\%), followed by the contemporary oral modality (COM) (24\%) and classic period (13\%). In contrast, the percentage of the verbs in variation in the EP, NP, and LEC (Contemporary written language) corresponds to $11 \%$ to each period.

The verbs of the preterit periods of Portuguese presented greater variability in relation to more recent periods. However, in the contemporary oral modality, this variability is still very frequent, almost as frequent as, in percentage terms, it is in the archaic period of the language.

The Figure 3 below indicates the evolution of the structures [de + infinitive $]$ and $[\varnothing+$ infinitive $]$ in the history of the Portuguese language. 


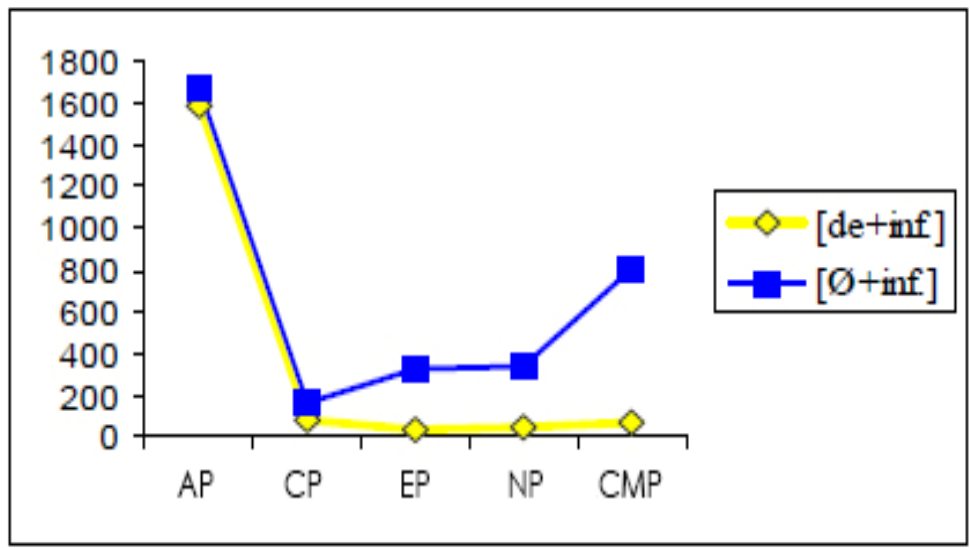

Figure 3. Evolution of the structures [de + infinitive] and $[\varnothing+$ infinitive $]$ in the history of the Portuguese language.

The Figure 3 indicates that the constructions in which appears the prepositioned infinitive decrease and the non-prepositioned constructions increase with time.

The results and the interpretations of the data lead us to identify internal factors intertwined in the occurrence of the investigated phenomena. They are adjacent structures (that cause fractions), verbal classes, verbal tense, verbal moods, and grammatical person.

\section{About the Adjacency}

The results obtained through the analysis of the phenomena of the adjacency/non adjacency (that causes fractions) of the verbs listed in the corpora proved that: (1) both prepositioned infinitive and non prepositioned infinitive occur predominantly adjacent to the regent verb and (2) when the non adjacency occurs, it prevails near the prepositioned infinitive, as the adjacency prevails near the non prepositioned infinitive.

\section{About the Semantic Classes}

Most authors who treated the infinitive variation state that it depends on some verbs/determined verbs. Among them are Barreto (1914), Carneiro Ribeiro (1950), Said Ali (1964), Almeida (1965), Maurer Jr. (1968), Dias (1970), Pontes (1973), Bynon (1983), Vitral (1987), Mattos e Silva (1989), Kury (1985), Beth Levin (1993), Madureira (2000), Neves (2000), and Bechara (2001).

Considering the meaning, the results obtained reveal that almost the totality of the verbs listed in the researched corpora can be included in the verbal class named "sensitives", expressing deliberation, modalization, frequency, benefit, among others. They also share characteristics of "modality" and "auxiliarity", mostly in the archaic period.

From the semantics point of view, these verbs share "modal aspects" and from the syntactic point of view, they share transitive characteristics. Therefore, it is possible to propose for this verbal class the label of modal-transitives. It was observed during the research that it is this verbal class that admits the variation of the infinitive complement.

\section{About Verbal Tense, Verbal Mood, and Grammatical Person}

After the analysis of the verbs in the five phases of the language, it was observed that for all the regent verbs of variable infinitive complement, the "preterit" (perfect and imperfect) prevailed, the indicative mood and the third grammatical person (singular/plural). These factors are present in the structures of [de + infinitive] as much as in the structures of [Ø+ infinitive]. 
The verbs whose infinitive complements are variable along the history of the Portuguese language occurred mostly in the "preterit" of the indicative mood and in the third person. These facts prove that the verbal classes, in which prevails the preterit tense, the third grammatical person, and the indicative mood are the most stable throughout time. In fact, these factors tend to remain, but not the verbs, in which they occur, because they have a differentiated behavior throughout time: some disappear, others remain transitive, others become no longer modal, and others become auxiliary. But, usually they preserve the preterit tense, the indicative mood, and the third grammatical person, in the constructions of the infinitive complementation.

The results seem to confirm what Manczak (1963) proposes as "general tendencies of the morphologic development", according to analog transformations. The author says that the preterit tense is more resistant to changes than other tenses, that the third person forms bear less analog chances than the other grammatical person, and that the indicative mood is also less submissive to change in relation to the other moods.

Although we are not addressing specifically of analogy cases, the persistence of a same verbal tense, verbal mood, and grammatical person throughout the history of Portuguese language, in the infinitive constructions, most certainly characterizes this kind of structure $[$ de + infinitive $] \sim[\varnothing+$ infinitive $]$ and reveals a certain morphosyntactic rigidity.

\section{Final Considerations}

According to the serial analysis of the verbs whose complements admit variation, it was possible to find that, in structural terms, the variable infinitive complement exists in every phase of the language. However, it does not occur with the same kind of verb. We postulate then, that the structural variation is conditioned to determined verbal class, that, from the syntactic point of view, can be used as transitives and from the semantic point of view, belongs to the class of the verbs called "sensitive", here named modal-transitives.

Among the structural factors contemplated, it was observed that the phenomenon of adjacency/non adjacency is intertwined in the relation of the infinitive complementation in the five phases of the Portuguese language. It was found that the infinitive complement, prepositioned or not, occurs mostly next to the regent verb. However, when the infinitive complement is not adjacent, in the older phases of the language, what prevail are the structures in which the prepositioned complements are. Differently, the non prepositioned structures occur next to the regent verbs. It means that [de + infinitive] correlates to non adjacency as much as [Ø + infinitive] correlates to adjacency, confirming the maxim "marks lead to marks" and "zeros lead to zeros". (Scherre, 1996).

In what concerns the frequency of the occurrence of the regent verbs that admitted variation, it was showed that:

(1) The variant [de + infinitive] and the number of regent verbs decrease with time;

(2) The variant $[\varnothing+$ infinitive $]$ increases;

(3) The variation of the infinitive complement as a whole decreases with time, but does not disappear.

It was also observed that the regency is not a fixed phenomenon in the language. It varies and changes with time. Each sync presents different regency. In the archaic period, the number of verbs that admit variability of the infinitive complement is bigger than the number of verbs with variable infinitive complement in the modern period. But the contemporary oral modality gets closer to the older periods. The number of verbs of the COM and the number of verbs of the AP are very close. To us, it happens because the written language of the AP presents many more orality characteristics than the contemporary written language. In that period, 
according to existent documents, people wrote as they spoke, therefore, the writing represented, roughly, the speech of that sync.

For the semantic class, it was found that most verbs which display the variable infinitive complement can be included in the "sensitive" class, which is subdivided in "deliberatives", "volitives", "benefactives", among others.

As for the innovations, they also unfold in the lexicon. The verbs agüentar [de + infinitivo]/endure [de + infinitive], evitar [de + infinitivo]/avoid [de + infinitive], inventar [de + infinitivo]/invent [de + infinitive], impedir [de + infinitivo]/prevent [de + infinitive], importar [de + infinitivo]/import [de + infinitive], negar [de + infinitivo $]$ deny $[\mathrm{de}+$ infinitive], proibir $[\mathrm{de}+$ infinitivo]/forbid $[\mathrm{de}+$ infinitive $]$, propor $[\mathrm{de}+$ infinitivo $]$ /propose $[\mathrm{de}+$ infinitive], recusar $[\mathrm{de}+$ infinitivo $] /$ refuse $[\mathrm{de}+$ infinitive $]$, reprimir $[\mathrm{de}+$ infinitivo]/repress [de + infinitive], topar [de + infinitivo]/bump into [de + infinitive], etc., keep the structure [de + infinitive] of the archaic Portuguese and lexically innovate, since with these verbs, the addressed complement does not appear in the preterit period of the language. It must be noticed that this syntactic structure that, at first sight, seems "sub-standard", in the current phase revealed itself, according to the consulted corpora, as a highly recurrent structure in the archaic phase of the language.

Before all the presented results and with base on the observed analysis, it is possible to state:

(1) The existence of variable syntactic phenomena in all the phases of the Portuguese language;

(2) That the variability is systematic and occurs as much in the present as in the past;

(3) That the variation depends on some lexical items;

(4) That the regency is not a fix phenomenon in the language;

(5) That the preposition "de" is highly productive in the system;

(6) That not always the most recurrent variant remains;

(7) That the variation proceeds gradually;

(8) That the change happens in different rhythms;

(9) That the complement is selected according to the verbal class.

From all that was said, it is impossible not to recognize the importance of the descriptive analysis that privileges the preterit periods of the language, mostly those further in time, for that is where we observe many facts that justify linguistic phenomena that are, at first sight, stigmatized in the contemporary language, especially in the oral modality.

We presented an analysis that had as its goal to describe and systematize the variation of the complements [de + infinitive $] \sim \varnothing+$ infinitive $]$ of the modal-transitive verbs in five periods of the Portuguese language. It was only possible through working with empirical historical data that configured, with the limitations inherent to all historical research, a cohesive corpus, essential condition to the entire discussion presented along this work.

\section{References}

Almeida, N. M. D. (1965). Gramática Metódica da Língua Portuguesa. São Paulo: Editora Saraiva.

Atkins, S., Clear, J., \& Ostler, N. (1992). Corpus design criteria. Literary and Linguistic Computing, 7(1), 1-16.

Barreto, M. (1914). Novíssimos Estudos da Língua Portuguesa. Coleção de Artigos. Rio de Janeiro: Livraria Francisco Alves. Bechara, E. (2001). Moderna Gramática Portuguesa. Rio de Janeiro: Editora Lucena.

Berber Sardinha, A. P. (2000). Padrões Lexicais e colocações do português. Lingüística de Corpus: Histórico e Problemática. D.E.L.T.A, 16(2), 323-367.

Bynon, T. (1983). Historical linguistics. London: Cambridge University Press. 
Carneiro Ribeiro, E. (1950). Serões Grammaticaes ou Nova grammatica Portugueza. Salvador: Livraria Progresso Editora Aguiar \& Souza LTDA.

Cohen, M. A. (2002). Línguas românicas em extinção: o francoprovençal. In R. Graciela and M. Arbex (Orgs.), Performance, exílio, fronteiras (pp. 265-280). Belo Horizonte: Departamento de Letras Românicas, Programa de Pós-Graduação em Letras: Estudos Literários, Faculdade de Letras/UFMG.

Dias, A. E. da S. (1970). Syntaxe Histórica Portuguesa (5a ed.). Lisboa: Livraria Clássica Editora.

Kury, A. da G. (1985). Novas Lições de Análise Sintática. São Paulo: Ática.

Labov, W. (1972a). Sociolinguistic patterns. Philadelphia: University of Pennsylvania Press.

Labov, W. (1972b). On the use of the Presente to explain the past. In L. Haiman (Org.), The Eleventh International Congress of Linguistics (pp. 825-851), Florence.

Labov, W. (1995). Principles of linguistic change, internal factors. Oxford: Blackwell.

Leal, M. A. da F. (2002). Sobre a história dos infinitivos introduzidos por de no português mineiro. In M. A. M.Cohen and J. Ramos (Orgs.), Dialeto mineiro e outras falas. Estudos de variação e mudança linguistic (Cap. 1, pp. 11-30). Belo Horizonte: Faculdade de Letras/UFMG.

Levin, B. (1993). English verb classes and alternations. Chicago and London: The University of Chicago Press.

Madureira, E. D. (2000). Difusão Lexical e Mudanças Sintático-Semânticas: os verbos psicológicos (Doutorado em Lingüística, Faculdade de Letras, Universidade Federal de Minas Gerais, Belo Horizonte).

Mańczak, W. (1963). Tendances Générales du développement morphologique. Língua, 12, 19-38.

Mattos e Silva, R. V. (1989). Estruturas Trecentistas. Lisboa: Imprensa Nacional—Casa da Moeda.

Maurer Jr., T. H. (1968). O infinitivo Flexionado Português. São Paulo: CIA Editora Nacional.

Milroy, J. (1992). Linguistic variation and change: On the historical sociolinguistics of English. GB: Blackwell.

Neves, M. H. M. (2000). Gramática de Usos do Português. São Paulo: UNESP.

Pontes, E. (1973). Verbos auxiliares em Português. Petrópolis: Vozes.

Said Ali, M. (1964). Gramática Histórica da Língua Portuguesa (3a ed). São Paulo: Edições Melhoramentos.

Scherre, M. M. P., \& Silva, G. M. O. (Orgs.). (1996). Padrões Sociolinguísticos: análise de fenômenos variáveis do português falado na cidade do Rio de Janeiro. Tempo Brasileiro, 85-117.

Sinclair, J. (1991). Corpus, concordance, collocation. Oxford: Oxford University Press.

Sinclair, J. (1995). From theory to practice. In G. Leech, G. Myers, and J. Thomas (Orgs.), Spoken English on computer-Transcription, mark-up and application. London: Longman.

Weinreich, U., Labov, W., \& Herzog, M. (1968). Empirical foundations for a theory of language change. In W. P. Lehmann and J. Malkiel (Orgs.), Directions for historical linguistics. Austin: University of Texas Press.

Tarallo, F. L. (1983). Relativization strategies in Brazilian Portuguese (Ph.D. dissertation, University of Pennsylvania, Philadelphia)

Tarallo, F. L. (1986). A Pesquisa Sociolinguística (2a ed.). São Paulo: Ática.

Vitral, L. (1987). Sobre a complementação infinitiva em Português (Dissertação, Mestrado em Linguística, Faculdade de Letras, Universidade Federal de Minas Gerais, Belo Horizonte). 